\title{
Chemical profile of the North American native Myriophyllum sibiricum compared to the invasive $M$. spicatum
}

\author{
Michelle D. Marko ${ }^{\mathrm{a}, \mathrm{b}, *}$, Elisabeth M. Gross ${ }^{\mathrm{c}}$, Raymond M. Newman ${ }^{\mathrm{a}}$, Florence K. Gleason ${ }^{\mathrm{b}}$ \\ ${ }^{a}$ University of Minnesota, Department of Fisheries, Wildlife and Conservation Biology, 1980 Folwell Avenue, St. Paul, MN 55108, USA \\ ${ }^{\mathrm{b}}$ University of Minnesota, Department of Plant Biology, 1445 Gortner Avenue, St. Paul, MN 55108, USA \\ ${ }^{\mathrm{c}}$ Limnological Institute, University of Konstanz, PO Box M659, 78457 Konstanz, Germany \\ Received 7 September 2006; received in revised form 10 August 2007; accepted 27 August 2007 \\ Available online 2 September 2007
}

\begin{abstract}
Myriophyllum spicatum L. is a nonindigenous invasive plant in North America that can displace the closely related native Myriophyllum sibiricum Komarov. We analyzed the chemical composition (including: C, N, P, polyphenols, lignin, nonpolar extractables, and sugars) of $M$. spicatum and $M$. sibiricum and determined how the chemistry of the two species varied by plant part with growing environment (lake versus tank), irradiance (full sun versus 50\% shading), and season (July through September). M. spicatum had higher concentrations of carbon, polyphenols and lignin (C: 47\%; polyphenols: 5.5\%; lignin: 18\%) than M. sibiricum (C: 42\%; polyphenols: 3.7\%; lignin: 9\%) while M. sibiricum had a higher concentration of ash under all conditions (12\% versus $8 \%$ for $M$. spicatum). Apical meristems of both species had the highest concentration of carbon, polyphenols, and tellimagrandin II, followed by leaves and stems. Tellimagrandin II was present in apical meristems of both $M$. spicatum $\left(24.6 \mathrm{mg} \mathrm{g}^{-1} \mathrm{dm}\right)$ and $M$. sibiricum $\left(11.1 \mathrm{mg} \mathrm{g}^{-1} \mathrm{dm}\right.$ ). Variation in irradiance from 490 (shade) to 940 (sun) $\mu \mathrm{mol}$ of photons $\mathrm{m}^{-2} \mathrm{~s}^{-1} \mathrm{had}_{\mathrm{no}}$ effect on $\mathrm{C}, \mathrm{N}$, and polyphenol concentrations, suggesting that light levels above $490 \mu \mathrm{mol}$ of photons $\mathrm{m}^{-2} \mathrm{~s}^{-1}$ do not alter chemical composition. The higher concentration of polyphenols and lignin in $M$. spicatum relative to $M$. sibiricum may provide advantages that facilitate invasion and displacement of native plants.
\end{abstract}

Keywords: Myriophyllum spicatum; Plant defense; Invasive species; Macrophyte; Polyphenol

\section{Introduction}

Myriophyllum spicatum $\mathrm{L}$. is a nuisance aquatic macrophyte nonindigenous to North America. Upon invasion of a new site, M. spicatum spreads rapidly, outcompeting native plants, altering the ecological community and impeding human activities (Smith and Barko, 1990). One closely related species that can be displaced by $M$. spicatum is northern watermilfoil, Myriophyllum sibiricum Komarov, a plant that is native to the aquatic habitats of the northern United States of America and southern Canada (Aiken, 1981; Moody and Les, 2002). M. sibiricum is morphologically and chemically very similar to $M$. spicatum (Ceska, 1977; Marko et al., 2005); however, small differences between the species may play a significant role in

\footnotetext{
* Corresponding author at: Department of Soil and Water, The Connecticut Agricultural Experiment Station, Box 1106, 123 Huntington Street, New Haven, CT 06504, USA. Tel.: +1 203974 8610; fax: +1 2039748502.

E-mail address: mmarko@umn.edu (M.D. Marko).
}

their ecological interactions with associated periphyton and invertebrate communities.

M. spicatum produces a high concentration of polyphenols relative to other aquatic plants (Smolders et al., 2000; Choi et al., 2002; Li et al., 2004). These compounds have been shown to limit the growth of the lepidopteran herbivore, Acentria ephemerella (Choi et al., 2002), and the snail, Radix swinhoei (Li et al., 2004). Furthermore, the polyphenol, tellimagrandin II, inhibits the growth of algae and cyanobacteria (Gross et al., 1996; Leu et al., 2002). Much less is known about the concentrations of polyphenols or other chemicals in $M$. sibiricum or their effects on aquatic organisms (Spencer and Ksander, 1999b). A comparison of the nutritive and defensive chemical profiles of $M$. spicatum and $M$. sibiricum should provide a better understanding of the plants' potential effects on herbivores and their ability to compete.

Plant chemistry is influenced by environmental factors, including light quality and quantity, sediment composition, and season. High irradiance has been shown to increase production 
of flavonoids, polyphenols, and lignins (Rozema et al., 1999; Smolders et al., 2000; Cronin and Lodge, 2003; Gross, 2003). The chemical composition of sediment affects the nutritive and mineral content of watermilfoils, which obtain mineral resources through their roots (Nichols and Keeney, 1976). Nutrient availability also impacts the production of particular natural products, such as the polyphenol, tellimagrandin II (Gross, 2003). In addition, seasonal differences in nutrient and defensive chemistry have been observed for $M$. spicatum populations (Spencer and Ksander, 1999a; Gross, 2000), and these changes may influence the ability of the plants to deal with competitors and consumers.

In addition to chemical variations due to abiotic influences, differences in the chemical composition of different plant parts and variations in the production of polyphenols as a function of age have also been reported (Gross, 2000). For example, apical meristems of $M$. spicatum were found to have a lower $\mathrm{C}: \mathrm{N}$ ratio and a higher polyphenolic content than lower portions of the stem (Gross, 2000). If chemical composition varies by plant part, consumers that feed only on a specific portion may be affected more than consumers that eat the entire plant.

To compare the chemical similarities and differences of the exotic and native milfoils, the chemical composition of plants harvested from lakes and plants grown in a common environment was determined. We further analyzed plant chemicals as they differed by plant part. To determine the effect of irradiance and season on the chemical composition, plants were grown under controlled conditions in either full sunlight or $50 \%$ shade over a 3 -month period.

\section{Methods}

\subsection{Collection and preparation of plants}

Plants were collected from three Minnesota (USA) lakes for direct analysis and for common environment experiments. $M$. spicatum was collected from Lake Auburn (Carver Co., MN, USA; T116N, R24W, S10) in July and August of 2001 and July of 2002 and from Cedar Lake (Hennepin Co., MN, USA; T29N, $\mathrm{R} 24 \mathrm{~W}, \mathrm{~S} 29$ ) in June 2000. Biomass (wet) of M. spicatum in Lake Auburn was $1640 \mathrm{~g} \mathrm{~m}^{-2}$ in July and $1550 \mathrm{~g} \mathrm{~m}^{-2}$ August of 2001 and $1775 \mathrm{~g} \mathrm{~m}^{-2}$ in August of 2002 with stem densities of 190, 120, and $230 \mathrm{~m}^{-2}$, respectively (Newman, 2004). Biomass of M. spicatum in Cedar Lake was $2050 \mathrm{~g} \mathrm{~m}^{-2}$ in June 2000 with a stem density of $176 \mathrm{~m}^{-2}$. M. sibiricum was collected from Christmas Lake (Hennepin Co., MN, USA; T117N, R23W, S35, 36) in July and August of 2001, July 2002, and July 2003. Visual estimates of M. sibiricum stem densities in Christmas Lake were between 20 and $70 \mathrm{~m}^{-2}$ for all years. In 2002, to compare plants grown in common environments, $M$. spicatum from Lake Auburn and $M$. sibiricum from Christmas Lake were grown in $600 \mathrm{~L}$ outdoor tanks $(185 \mathrm{~cm} \times 65 \mathrm{~cm}$ $\times 50 \mathrm{~cm}, l \times w \times d)$. The tank sediment consisted of a mixture of lake sediment and a sand:loam mix (50:50) that was homogenized and added to the tanks to a depth of 4-7 cm. Sediment bulk density $\left(\mathrm{g} \mathrm{dm} \mathrm{mL}^{-1}\right)$, percentage organic matter, combined total $\mathrm{NH}_{4}-\mathrm{N}$ from pore water $\left(\mathrm{NH}_{4}-\mathrm{N}\right.$ of pore water $\mathrm{mg} \mathrm{L}^{-1}$ ) and sediment (KCl-exchangeable $\mathrm{N}$ of sediment; $\mathrm{mg} \mathrm{g}^{-1} \mathrm{dm}$ ) were determined (Newman, 2004). Each tank was filled half-way with tap water and allowed to equilibrate for 2 days before planting with $20 \mathrm{~cm}$ cuttings of each species for a stem density of $166 \mathrm{~m}^{-2}$. Algae were manually removed from the tanks throughout the experiment. After the milfoils were rooted, the water levels were maintained at $45 \mathrm{~cm}$. Plant samples were collected from the tanks in August after 1 month of growth.

Lake plant samples were collected from stands with no apparent herbivore damage. Shoots were detached from the plant and held in lake water until laboratory processing, which occurred within $24 \mathrm{~h}$ of collection. The plant tops (up to $20 \mathrm{~cm}$ ) were inspected for herbivore damage and cleaned of algae and detritus. Plants were spun in a salad spinner for $15 \mathrm{~s}$ to remove excess water, weighed, and frozen at $-20{ }^{\circ} \mathrm{C}$ until analysis.

Frozen stems $(6-20 \mathrm{~cm}$, including apical meristem) were lyophilized whole or separated as follows: apical meristem $(\mathrm{AM})$, the top $2-3 \mathrm{~cm}$ to where the internode length was $<0.5 \mathrm{~cm}$; stem (S), up to $20 \mathrm{~cm}$ in length excluding the apical meristem; and leaf (L), and then lyophilized. The dried material was ground to a powder that would pass through a $1 \mathrm{~mm}$ mesh screen with either a mortar and pestle or pulverized for $10 \mathrm{~min}$ in a mixer mill.

\subsection{Light manipulation}

We determined the effect of light attenuation versus full sun exposure on M. spicatum over the course of 90 days. Irradiance was manipulated by using $50 \%$ shade cloth to cover three, $378 \mathrm{~L}$ tanks $(132 \mathrm{~cm} \times 69 \mathrm{~cm} \times 71 \mathrm{~cm}, l \times w \times d)$, and leaving three tanks exposed to direct sunlight. All tanks were covered with "noseeum" nylon netting (0.3 mm mesh, Venture Textiles, Inc., Braintree, MA) to prevent contamination from debris or herbivores. The late morning irradiance at the water surface was $936 \pm 96 \mu \mathrm{mol}$ of photons $\mathrm{m}^{-2} \mathrm{~s}^{-1}$, and underneath the shade cloth, the irradiance was $488 \pm 62 \mu \mathrm{mol} \mathrm{m}{ }^{-2} \mathrm{~s}^{-1}$ (LiCor LI-185). Tanks were prepared as above and planted with 150 , $30 \mathrm{~cm}$ cuttings of $M$. spicatum from Lake Auburn for a stem density of $165 \mathrm{~m}^{-2}$. Sediment bulk density, percent organic matter, and total $\mathrm{N}$ were determined for each tank. Bulk density, percent organic matter, pore water $\mathrm{NH}_{4}-\mathrm{N}$ and total $\mathrm{N}$ of sediment from $M$. spicatum tanks $\left(1.0 \mathrm{~g} \mathrm{dm} \mathrm{mL}^{-1}, 4.0 \%\right.$, $2.17 \mathrm{mg} \mathrm{L}^{-1}, 0.002 \mathrm{mg} \mathrm{g}^{-1}$, respectively) were very similar to those of $M$. sibiricum tanks (1.8 $\mathrm{g} \mathrm{dm} \mathrm{mL}^{-1}, 5.6 \%, 2.54 \mathrm{mg} \mathrm{L}^{-1}$, $0.001 \mathrm{mg} \mathrm{g}^{-1}$, respectively). Bulk density of sediment from tanks was higher than sediment from Lake Auburn $\left(0.55 \mathrm{~g} \mathrm{dm} \mathrm{mL}^{-1}\right)$, while percent organic matter, pore water $\mathrm{NH}_{4}-\mathrm{N}$ and total $\mathrm{N}$ of sediment from tanks were lower than those from Lake Auburn $\left(15.3 \%, 5.3 \mathrm{mg} \mathrm{L}^{-1}, 0.033 \mathrm{mg} \mathrm{g}^{-1}\right.$, respectively).

The length of 15 randomly selected stems was measured from each tank every 5 days from 27 June 2002 to 24 September 2002 to assess submersed growth. Plants with flowering meristems were cut back to a lateral meristem. The top $20 \mathrm{~cm}$ of 50 long, non-flowering apical meristems were collected every 10-20 days from each tank from 16 July 2002 to 24 September 
2002. Long stems were removed to minimize self-shading and to ensure collection of actively growing stems. After stem removal, the length of 15 randomly selected remaining stems was measured to develop a base point for measuring growth over the subsequent 10 - to 20-day period. Growth rate $(\mathrm{cm}$ increase per day) was determined using the average growth over each 10- to 20-day period that occurred between plant removals. Wet mass was determined for the removed stems after spinning for $15 \mathrm{~s}$ in a salad spinner. Stems were placed in plastic bags and frozen at $-20{ }^{\circ} \mathrm{C}$ until analysis.

\subsection{Chemical analyses}

Milfoil stems were analyzed for carbon and nitrogen content with a Costech ECS 4010 (Costech Analytical, Valencia, CA) by the University of Nebraska, Lincoln, NE, or with an Elementar Analysator NCS 2500 (CE Instruments/Thermoquest, Milan, Italy) at the University of Konstanz, Germany. Phosphorus was measured using the acid extraction method and colorimetric analysis with an AutoAnalyzer 3 (AA3, BranLuebbe, Germany) by the University of Nebraska. Molar ratios of $\mathrm{C}: \mathrm{N}, \mathrm{C}: \mathrm{P}$, and $\mathrm{C}: \mathrm{N}$ were calculated and used in statistical analyses. Total phenolic compounds (TPC) were determined with the Folin-Ciocalteu assay using tannic acid as the standard (Gross et al., 1996). Results were expressed as tannic acid equivalents (TAE) based on dry mass.

Tellimagrandin II (T-II) was quantified using HPLC (Gross et al., 1996). The presence of T-II in the HPLC fractions was confirmed by negative ion electrospray (ESI) mass spectrometry. A $5 \mu \mathrm{L}$ sample of the presumed T-II fraction from the HPLC elution was injected into a ThermoElectron LCQ classic ion trap mass spectrometer. The column flow rate was $25 \mu \mathrm{L} \mathrm{min}^{-1}, 25 \%$ methanol in water. Full scan was from 150 to $1200 \mathrm{~m} / \mathrm{z}$. MS/MS was used to isolate the peak at $937.2 \mathrm{~m} / \mathrm{z}$ corresponding to T-II. The product ion spectra were collected from 255 to $1000 \mathrm{~m} / \mathrm{z}$. The largest product ion peak occurred at $767.06 \mathrm{~m} / \mathrm{z}$, matching the loss of one gallic acid from T-II. Spectra of the extract from $M$. sibiricum matched the standard T-II extracted from M. spicatum (Gross et al., 1996).

Dried plant samples were also analyzed for concentrations of various carbon fractions (Ryan et al., 1990) at the Center for Water and the Environment (Natural Resources Research Institute, University of Minnesota, Duluth, Minnesota) according to forest products techniques (Ryan et al., 1990; Hobbie, 1996). Each sample (a composite of more than 10 stems) was analyzed for ash, nonpolar extractives (NPE: fats, oils, waxes and chlorophylls), water-soluble compounds (WS: simple sugars, soluble polyphenols, amino acids), acidsoluble compounds (AS: polysaccharides, polypeptides, nucleic acids) and insoluble material, which consists of lignin and other indigestible materials, hereafter lignin. The water-soluble component was further analyzed for total phenolic compounds (Folin-Denis method), measured as tannic acid equivalents, and for simple sugars, measured as percent glucose equivalents. The acid-soluble component was further analyzed for polysaccharides (cellulose, hemicellu- lose, starch) measured as percent glucose equivalents. Lignin is the material remaining after all extractions and may include phenylpropanoids or structurally bound polyphenols. All carbon fraction data are presented as percentages based on ash-free dry mass.

\subsection{Statistical analyses}

Data were analyzed with SAS 9.1 (SAS Institute Inc., Cary, NC). Data were tested for normal distribution (K-S test or Shapiro-Wilk test) and variance homogeneity (Levene's test). Extreme outliers were removed (Ott, 1993). A log transformation was performed with proportional data that did not meet the tests for normality and homogeneity. Upon transformation, distribution criteria were met. A two-way ANOVA (GLM procedure) was used for the analysis of $\mathrm{C}, \mathrm{N}$, $\mathrm{P}, \mathrm{C}: \mathrm{N}, \mathrm{C}: \mathrm{P}$, and $\mathrm{N}: \mathrm{P}$ data using species, date (one factor for both month and year) and the interaction species by date as factors. When the date by species interaction was significant, a one-way ANOVA (GLM procedure) for each date with species as a factor was performed to determine whether $\mathrm{C}, \mathrm{N}$, $\mathrm{P}, \mathrm{C}: \mathrm{N}, \mathrm{C}: \mathrm{P}$, and $\mathrm{N}: \mathrm{P}$ were significantly different between species. To determine whether $\mathrm{C}, \mathrm{N}, \mathrm{P}, \mathrm{C}: \mathrm{N}, \mathrm{C}: \mathrm{P}$, and $\mathrm{N}: \mathrm{P}$ varied by season (July versus August) and growing environment (lake versus tank) within a species, a one-way ANOVA was performed for each species with date as a factor. The effect of season on $\mathrm{C}, \mathrm{N}, \mathrm{P}, \mathrm{C}: \mathrm{N}, \mathrm{C}: \mathrm{P}$, and $\mathrm{N}: \mathrm{P}$ was determined using a linear contrast comparing samples collected in July versus August. The effect of environment on $\mathrm{C}, \mathrm{N}, \mathrm{P}, \mathrm{C}: \mathrm{N}, \mathrm{C}: \mathrm{P}$, and N:P was determined using a linear contrast within each species to compare samples collected from lakes versus tanks. Corrections for multiple comparisons were determined with Bonferroni's adjustment.

Differences among plant part and between species within each plant part were determined with an ANOVA (GLM procedure). Although each species was not collected at each lake or on the same day, the effect of lake and collection date was accounted for by including these factors in the general linear model and using Type III sums of squares. Samples from the light manipulation experiment were analyzed with repeated measures. A repeated-measures (date) ANOVA was performed for wet mass, growth rate and stem length as well as on the chemical parameters, $\mathrm{C}, \mathrm{N}, \mathrm{C}: \mathrm{N}$, total phenolic compounds (TPC), T-II, and T-II:TPC.

Constituents from the carbon fraction analysis were analyzed with a one-way ANOVA for each parameter with species as the main effect: ash, lignin, nonpolar extractives, water-soluble extractives, acid-soluble extractives, simple sugars, polysaccharides, polyphenols, lignin (all percentages) and lignin:N ratio. When significant differences among treatments were found, the ANOVAs were followed by Tukey's honest significant difference (hsd) test adapted for unequal sample sizes (Day and Quinn, 1989). Correlation of carbon with the constituents of the carbon fraction analysis was determined with the Pearson correlation statistic. Bonferroni's adjustment for multiple comparisons was used to account for experimentwise error using $\alpha=0.05$. 


\section{Results}

\subsection{Species, growing environment, and seasonal effects}

The chemical composition of M. spicatum and M. sibiricum are very similar for all parameters except carbon content. Carbon content of $M$. spicatum was higher than that of $M$. sibiricum for lake populations (d.f. $=1,35, F=102.6$, $P<0.0001)$ and milfoil grown in a common environment (d.f. $=1,24, F=13.36, P=0.0013$; Fig. 1a). No significant differences in $\mathrm{N}$ and $\mathrm{P}$ content, $\mathrm{C}: \mathrm{N}, \mathrm{C}: \mathrm{P}$, and $\mathrm{N}: \mathrm{P}$ ratios were found between $M$. spicatum and $M$. sibiricum grown in a common environment (Fig. 1b-f), but several differences occurred between species collected from different lakes or at different times during the summer. These differences could reflect lake or species differences. Nitrogen content of $M$. spicatum was significantly higher than in M. sibiricum for July samples, but was significantly lower than $M$. sibiricum in August 2001 (Fig. 1b). The C:N ratio of M. spicatum was significantly lower in July, but was significantly greater than that of M. sibiricum in August 2001 (Fig. 1c). Phosphorus content of $M$. spicatum was significantly higher than that of $M$.

M. spicatum ○ M. sibiricum
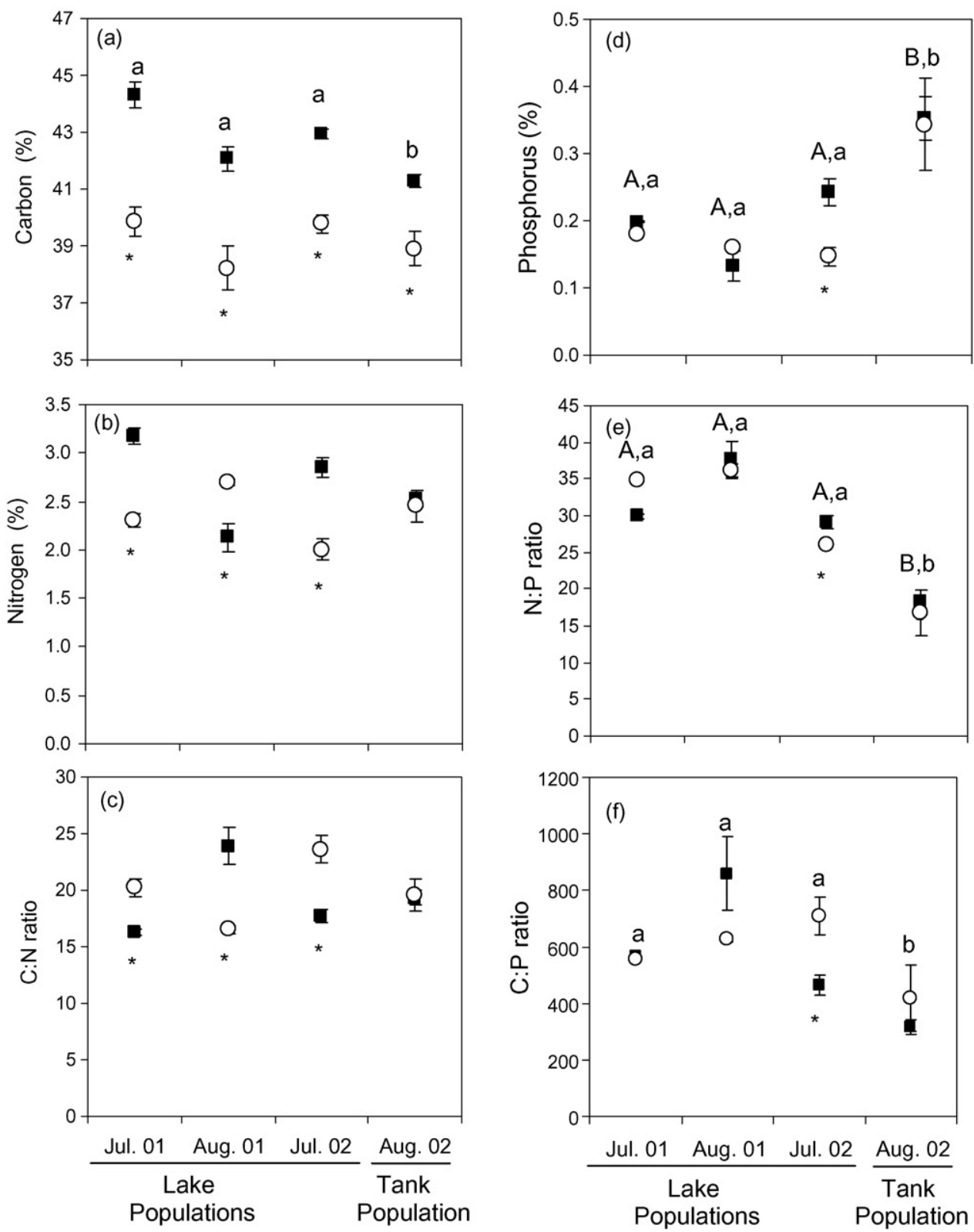

Fig. 1. Carbon (a), nitrogen (b), and phosphorus (d) content and C:N (c), N:P (e) and C:P (f) molar ratios (mean \pm 1 S.E.) for $M$. spicatum (solid squares) and M. sibiricum (open circles) collected in July and August of 2001 and in July 2002 from lake populations and in August 2002 from outdoor tank populations of both species. The number of samples per treatment was 4, 9, 9, 13 and 4, 6, 9, 13 (July 01, August 01, July 02, August 02) for C and N content and C:N ratio of M. spicatum and $M$. sibiricum, respectively and 2, 3, 3,8 and 1, 4, 3, 7 for $\mathrm{P}$ content and N:P and C:P ratios of $M$. spicatum and $M$. sibiricum, respectively. For each date, significant differences $(P<0.05)$ between species are indicated $\left(^{*}\right)$ based on $F$-tests. For each growing environment (lake vs. tank), significant differences are indicated in lower case for $M$. spicatum and capitalized for $M$. sibiricum. 
sibiricum in July 2002 (Fig. 1d). The N:P ratio of M. spicatum was less than that of M. sibiricum in July 2002 (Fig. 1e), and the C:P ratio of $M$. spicatum was less than that of $M$. sibiricum in July 2002 (Fig. 1f).

Carbon content was higher in $M$. spicatum collected from lakes than from plants grown in a common environment, but a similar difference was not observed for M. sibiricum (Fig. 1a). No differences between lake and tank populations were found for $\mathrm{N}$ content or $\mathrm{C}: \mathrm{N}$ ratio. Phosphorus content was significantly lower in lake populations versus tank populations for both M. spicatum and M. sibiricum (Fig. 1d). The N:P ratio was higher in lake versus tank populations of M. spicatum and M. sibiricum (Fig. 1e). The C:P ratio was also higher in lake versus tank populations of $M$. spicatum, but not for the $M$. sibiricum populations (Fig. 1f).

Apical meristems had a higher concentration of carbon, nitrogen, total phenols, tellimagrandin II and percent T-II:TPC, and a lower $\mathrm{C}: \mathrm{N}$ ratio than leaves or stems (Table 1). Leaves had a higher concentration of carbon and nitrogen than stems. Concentrations of polyphenols and tellimagrandin II were approximately twice as high in the apical meristems of $M$. spicatum compared to M. sibiricum.

\subsection{Carbon fraction analysis}

Differences between milfoil species were observed for carbon, ash, polyphenols, lignin, and lignin: $\mathrm{N}$ ratio (Table 2). Carbon, polyphenols, lignin and lignin:N were higher in $M$. spicatum than in $M$. sibiricum. Ash content was higher in $M$. sibiricum. Correlations were calculated among the constituents that differed significantly by species. Carbon content was positively correlated with polyphenolic content $(r=0.81$, $P<0.05)$ and lignin $(r=0.74, P<0.05)$, and negatively correlated with ash content $(r=-0.93, P<0.05)$.

On further analysis of water-soluble components, these were found to be positively correlated with sugars $(r=0.88$, $P<0.05)$, but not correlated with polyphenols $(r=0.22$, $P>0.1)$. Therefore, the content of water-soluble components is a good estimation of sugar content, but may mask changes in
Table 2

Means ( \pm 1 S.E.) from carbon fractions analysis are listed for $M$. spicatum and $M$. sibiricum with associated $F$-statistics from one-way ANOVAs

\begin{tabular}{lccc}
\hline Variable & $F$ & $\begin{array}{l}\text { M. spicatum } \\
(N=7)\end{array}$ & $\begin{array}{l}\text { M. sibiricum } \\
(N=6)\end{array}$ \\
\hline$\% \mathrm{C}$ & $13.72^{* *}$ & $46.85(0.651)$ & $42.18(1.134)$ \\
$\% \mathrm{~N}$ & 0.19 & $2.75(0.221)$ & $2.64(0.135)$ \\
$\mathrm{C}: \mathrm{N}$ & 0.51 & $20.76(1.94)$ & $19.03(1.44)$ \\
$\%$ Ash & $8.12^{*}$ & $7.94(0.800)$ & $12.08(1.31)$ \\
$\% \mathrm{NPE}$ & 0.26 & $11.37(2.32)$ & $9.65(2.43)$ \\
$\% \mathrm{WS}$ & 0.01 & $18.53(2.07)$ & $18.22(1.52)$ \\
$\%$ AS & $6.30^{*}$ & $52.53(2.68)$ & $62.88(3.17)$ \\
$\%$ WS sugars & 0.75 & $5.44(1.19)$ & $4.25(0.542)$ \\
$\%$ Polysaccharides & 0.22 & $27.53(3.38)$ & $29.53(2.36)$ \\
\%Polyphenols & $11.91^{* *}$ & $5.46(0.377)$ & $3.74(0.310)$ \\
\%Lignin & $12.22^{* *}$ & $17.57(2.08)$ & $9.25(0.806)$ \\
Lignin:N & $15.68^{* *}$ & $6.46(0.622)$ & $3.55(0.315)$ \\
\hline
\end{tabular}

$F$-Value and its significance are indicated for the model as determined by the one-way ANOVA. Due to the quantity of material needed for carbon fraction analysis, only a limited number of samples were analyzed, though each sample was a composite of more than 10 stems. NPE: fats, oils, waxes and chlorophylls. WS: simple sugars, hydroxyphenol groups, amino acids. AS: cellulose, hemicellulose, and starch. Lignin: $\mathrm{N}$ ratio is not a molar ratio. d.f. $=2,12$, except for ash, d.f. $=2,11$

* Significance at $P<0.05$.

** Significance at $P<0.01$.

phenolic content. Acid-soluble components were further analyzed for polysaccharides, but ash is also acid soluble and may dissolve in this fraction. Lignin is the material remaining after all extractions are done. Therefore, we tested whether acid-soluble components were correlated with either polysaccharides, ash, or lignin and found that they were positively correlated with polysaccharides $(r=0.72, P<0.05)$, but not correlated with ash $(r=0.10, P>0.1)$ or lignin $(r=-0.10, P>0.1)$. Thus, the acid-soluble component reflects polysaccharide content, not ash or lignin.

\subsection{Light manipulation-effect on M. spicatum}

Shaded stems were marginally longer than stems of plants exposed to full light, $46.6 \pm 1.32 \mathrm{~cm}$ versus $39.5 \pm 1.02 \mathrm{~cm}$

Table 1

Mean ( \pm 1 S.E.) carbon, nitrogen, phenolic and tellimagrandin II content and C:N and tellimagrandin II:polyphenols ratios and associated $F$-values for $M$. spicatum and $M$. sibiricum apical meristems, leaves and stems

\begin{tabular}{|c|c|c|c|c|c|c|c|c|c|}
\hline & \multirow[t]{2}{*}{$\mathrm{N}$} & \multicolumn{3}{|l|}{ M. spicatum } & \multicolumn{3}{|l|}{ M. sibiricum } & \multicolumn{2}{|l|}{$F$-Statistics } \\
\hline & & $\begin{array}{l}\text { Apical } \\
\text { meristems }\end{array}$ & Leaves & Stems & $\begin{array}{l}\text { Apical } \\
\text { meristems }\end{array}$ & Leaves & Stems & $\begin{array}{l}\text { Plant part } \\
(\text { d.f. = 2) }\end{array}$ & $\begin{array}{l}\text { Species } \\
(\text { d.f. }=1)\end{array}$ \\
\hline$\% \mathrm{C}$ & $10 \pm 2$ & $45.55(0.48)$ & $43.85(0.29)$ & $41.97(0.52)$ & $43.18(0.88)$ & $40.58(0.44)$ & $38.89(0.66)$ & $37.40^{* * *}$ & $30.58^{*}$ \\
\hline$\% \mathrm{~N}$ & $10 \pm 2$ & $3.95(0.18)$ & $2.89(0.17)$ & $1.47(0.13)$ & $3.51(0.19)$ & $2.74(0.092)$ & $1.51(0.078)$ & $134.38^{* * *}$ & 0.12 \\
\hline$C: N$ & $10 \pm 2$ & $13.72(0.67)$ & $18.54(1.39)$ & $37.56(4.06)$ & $14.86(1.03)$ & $17.41(0.50)$ & $30.56(1.14)$ & $124.09^{* * *}$ & 1.56 \\
\hline Polyphenols ( $\mathrm{mg} \mathrm{g}^{-1} \mathrm{dm}$ ) & $6 \pm 1$ & $107.8(16.23)$ & $56.5(6.92)$ & $73.8(8.49)$ & $65.5(11.08)$ & $24.6(3.17)$ & $29.3(2.68)$ & $11.48^{* *}$ & $45.97^{*}$ \\
\hline T-II $\left(\mathrm{mg} \mathrm{g}^{-1} \mathrm{dm}\right)$ & $6 \pm 1$ & $24.58(5.63)$ & $9.47(1.94)$ & $6.02(1.47)$ & $11.09(3.66)$ & $3.05(0.73)$ & $3.11(0.49)$ & $15.43^{* * *}$ & 4.48 \\
\hline T-II:polyphenols & $6 \pm 1$ & $20.99(3.49)$ & $14.24(1.66)$ & $9.33(0.83)$ & $14.86(2.42)$ & $11.20(2.17)$ & $10.33(1.19)$ & $6.23^{* *}$ & 3.96 \\
\hline
\end{tabular}

$F$-statistics for two-way ANOVAs are for plant part and species (within plant part) as factors for M. spicatum and $M$. sibiricum plant chemistry. Data are for plants collected from 2000 to 2003 from lake and tank populations.

* Significance at $P<0.05$.

** Significance at $P<0.01$.

*** Significance at $P<0.001$. 
Table 3

Mean ( \pm 1 S.E.) carbon, nitrogen, polyphenolic and tellimagrandin II content and C:N and tellimagrandin II:polyphenols ratios $(N=3)$ and associated $F$-statistic for M. spicatum seasonal effects (irradiance treatment was not significant in two-way ANOVAs)

\begin{tabular}{|c|c|c|c|c|c|c|c|}
\hline \multirow[t]{2}{*}{ Variable } & \multirow[t]{2}{*}{ Treatment } & \multicolumn{5}{|l|}{ Date } & \multirow{2}{*}{$\begin{array}{l}\text { Season } \\
F(\text { d.f. }=4)\end{array}$} \\
\hline & & 16 July & 5 August & 20 August & 9 September & 24 September & \\
\hline \multirow[t]{2}{*}{$\% \mathrm{C}$} & Sun & $46.12(0.31)$ & $46.06(0.03)$ & $45.67(0.12)$ & $46.04(0.19)$ & $45.86(0.08)$ & \multirow[t]{2}{*}{$3.31^{*}$} \\
\hline & Shade & $45.86(0.12)$ & $46.53(0.24)$ & $45.64(0.20)$ & $46.50(0.09)$ & $45.99(0.36)$ & \\
\hline \multirow[t]{2}{*}{$\% \mathrm{~N}$} & Sun & $4.93(0.18)$ & $4.40(0.24)$ & $3.85(0.28)$ & $4.22(0.29)$ & $4.64(0.04)$ & \multirow[t]{2}{*}{$8.46^{* *}$} \\
\hline & Shade & $4.93(0.13)$ & $4.56(0.25)$ & $3.91(0.37)$ & $4.38(0.08)$ & $4.42(0.20)$ & \\
\hline \multirow[t]{2}{*}{$\mathrm{C}: \mathrm{N}$} & Sun & $11.00(0.39)$ & $12.29(0.72)$ & $14.04(1.14)$ & $12.92(0.88)$ & $11.55(0.10)$ & \multirow[t]{2}{*}{$6.80^{* *}$} \\
\hline & Shade & $10.88(0.29)$ & $11.98(0.56)$ & $13.89(1.30)$ & $12.39(0.24)$ & $12.19(0.49)$ & \\
\hline \multirow[t]{2}{*}{ Polyphenols ( $\left.\mathrm{mg} \mathrm{g}^{-1} \mathrm{dm}\right)$} & Sun & $95.1(16.9)$ & $108.0(9.2)$ & $134.0(11.5)$ & $97.5(5.7)$ & $115.2(12.2)$ & \multirow[t]{2}{*}{1.82} \\
\hline & Shade & $110.9(5.8)$ & $118.4(12.5)$ & $110.6(11.6)$ & $103.9(4.4)$ & $123.0(9.1)$ & \\
\hline \multirow[t]{2}{*}{ Tellimagrandin II ( $\left.\mathrm{mg} \mathrm{g}^{-1} \mathrm{dm}\right)$} & Sun & $15.73(3.43)$ & $18.49(2.23)$ & $32.01(2.70)$ & $23.93(0.77)$ & $39.01(4.67)$ & \multirow[t]{2}{*}{$20.39^{* * * *}$} \\
\hline & Shade & $21.04(1.05)$ & $22.66(3.54)$ & $24.13(1.71)$ & $26.50(1.60)$ & $43.73(4.72)$ & \\
\hline \multirow[t]{2}{*}{ T-II:polyphenols } & Sun & $16.43(0.79)$ & $17.02(0.70)$ & $23.80(1.82)$ & $24.71(2.29)$ & $33.84(0.51)$ & \multirow[t]{2}{*}{$63.70^{* * *}$} \\
\hline & Shade & $18.92(0.51)$ & $18.93(1.14)$ & $22.03(1.23)$ & 25.59 (1.44) & 35.35 (1.34) & \\
\hline
\end{tabular}

${ }_{*}^{*}$ Significance at $P<0.05$.
** Significance at $P<0.01$.
*** Significance at $P<0.001$.

(d.f. $=1, \quad F=6.14, \quad P=0.07)$. Stem length also varied significantly by date (d.f. $=23, F=69.19, P<0.0001$ ) with stems from the first 3.5 weeks being shorter than stems from the remaining 8.5 weeks of the experiment (d.f. $=1, F=119.21$, $P<0.0001)$. Average growth rate throughout the summer was $0.63 \pm 0.22 \mathrm{~cm} \mathrm{day}^{-1}$ for the shaded stems and $0.50 \pm$ $0.20 \mathrm{~cm} \mathrm{day}^{-1}$ for stems exposed to full sun. The growth rate decreased over the summer (d.f. $=5, F=9.46, P<0.0001$ ) as did meristem mass (d.f. $=4, F=9.07, P=0.0005)$. Sunexposed stems had significantly greater wet mass in mid-July (d.f. $=4, F=12.17, P=0.013$ ) and early September than shaded plants (d.f. $=4, F=7.95, P=0.048$ ), but overall wet mass was not significantly different, $67.0 \pm 3.06 \mathrm{~g}$ for sun versus $54.0 \pm 3.15 \mathrm{~g}$ for shaded plants (d.f. $=1, F=4.57$, $P=0.10)$. Shading did not affect sediment characteristics nor the following chemical characteristics of $M$. spicatum: carbon, nitrogen, polyphenolic or tellimagrandin II content, C:N, and T-
II:TPC ratios (Table 3). However, several chemical parameters did vary significantly over time indicating a seasonal effect on chemical composition. Nitrogen content was lowest in August and highest in July and September (Table 3) while the C:N ratio was highest in August and lowest in July and September. Tellimagrandin II content and the proportion of tellimagrandin II to polyphenols increased from July to September (Table 3) although total phenolic content showed no seasonal effects.

\subsection{Relationship of $C: N$ ratio to phenolic compounds}

We assessed the correlation of total phenolic compounds and one major polyphenol, tellimagrandin II, with the C:N ratio to determine the pattern of carbon allocation in different plant parts. Because plant part was a significant factor for chemical composition, we analyzed total phenolic and tellimagrandin II content of $M$. spicatum tissue as a function of the C:N molar

Table 4

Results of regression analysis for total phenolic content and tellimagrandin II (T-II) content based on C:N content for the plant parts of sun and shade-exposed $M$. spicatum

\begin{tabular}{|c|c|c|c|c|c|c|c|c|}
\hline & \multicolumn{4}{|c|}{ Total phenolic content } & \multicolumn{4}{|c|}{ Tellimagrandin II $^{\mathrm{a}}$} \\
\hline & d.f. & $F$ & $P$ & $r_{\text {adj }}^{2}$ & d.f. & $F$ & $P$ & $r_{\text {adj }}^{2}$ \\
\hline \multicolumn{9}{|l|}{ Apical meristems } \\
\hline Combined light treatments & 1,56 & 17.0 & 0.0001 & 0.22 & 1,56 & 5.21 & 0.0263 & 0.085 \\
\hline \multicolumn{9}{|l|}{ Leaves } \\
\hline Combined light treatments & & & & & 1,10 & 0.58 & 0.4650 & 0.055 \\
\hline Light-exposed & 1,4 & 6.93 & 0.0580 & 0.54 & & & & \\
\hline Shaded & 1,4 & 12.5 & 0.0242 & 0.70 & & & & \\
\hline \multicolumn{9}{|l|}{ Stems } \\
\hline Combined light treatments & & & & & 1,10 & 10.7 & 0.0085 & 0.47 \\
\hline Light-exposed & 1,4 & 1.24 & 0.3300 & 0.046 & & & & \\
\hline Shaded & 1,4 & 40.3 & 0.0032 & 0.89 & & & & \\
\hline
\end{tabular}

Regressions for total phenolic content correspond to Fig. 2 . Regression equations for Tellimagrandin II: apical meristem T-II $=-1.2+2.3 \times \mathrm{C}: \mathrm{N}$ ratio; leaves: T$\mathrm{II}=0.92+0.41 \times \mathrm{C}: \mathrm{N}$ ratio; stems: $\mathrm{T}-\mathrm{II}=7.54-0.085 \times \mathrm{C}: \mathrm{N}$ ratio. 

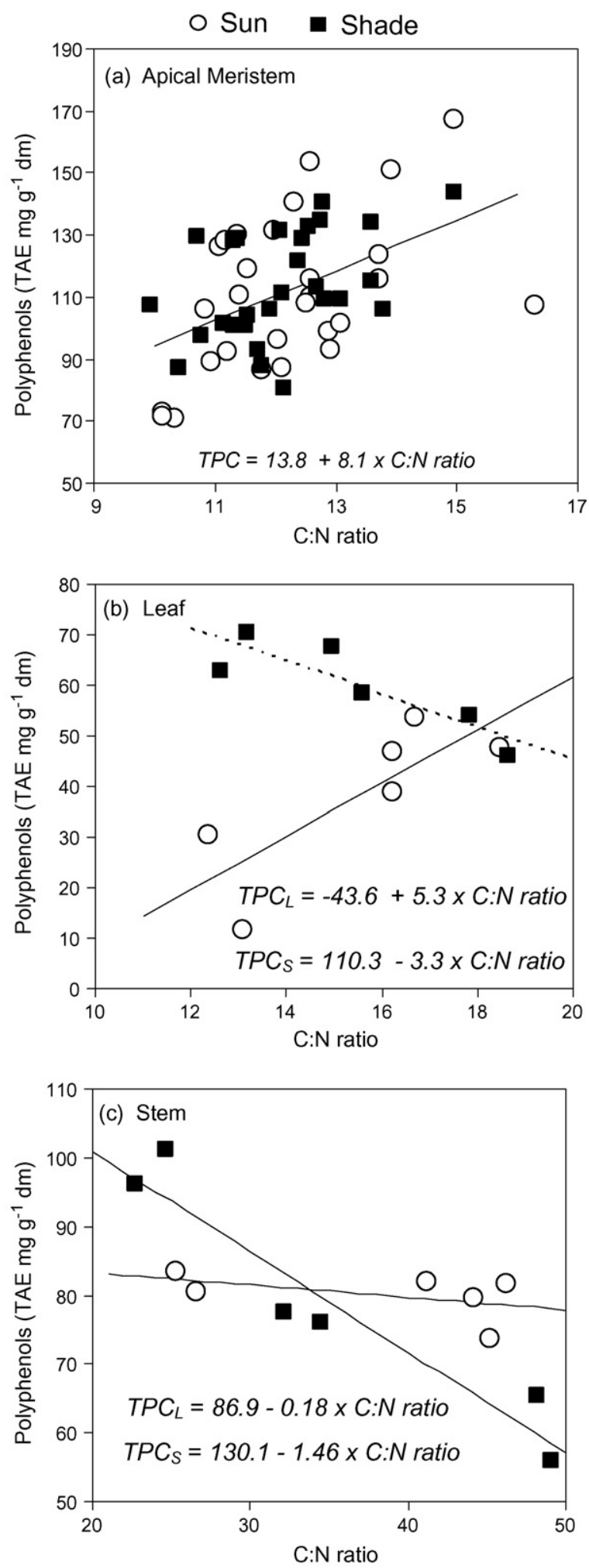

Fig. 2. Relationship between $\mathrm{C}: \mathrm{N}$ ratio and total phenolic content in sunexposed and shaded M. spicatum apical meristems (a), leaves (b), and stems (c). Regression lines are indicated within each graph. TPC $=$ total phenolic content, $\mathrm{TPC}_{\mathrm{L}}=$ total phenolic content of light exposed $M$. spicatum, $\mathrm{TPC}_{\mathrm{S}}=$ total phenolic content of shaded plants. See Table 4 for regression statistics. ratio separately for each plant part (apical meristems, leaves, and stems). An ANCOVA was used for total phenolic and tellimagrandin II content using $\mathrm{C}: \mathrm{N}$ ratio as a covariate and light treatment as a factor and subsequent regression analyses (see Gross, 2003). In apical meristems, total phenolic and tellimagrandin II content were unaffected by light intensity (TPC: d.f. $=1, F=0.22, P>0.10$; T-II: d.f. $=1, F=0.72$, $P>0.10$ ) and both increased with C:N ratios (Fig. 2a, Table 4). In leaves, light intensity strongly influenced total phenolic content (light: d.f. $=1, F=20.49, P=0.002 ;$ C:N: d.f. $=1$, $F=0.86, \quad P=0.38, \quad \mathrm{C}: \mathrm{N} \times$ light: $\quad$ d.f. $=1, \quad F=15.39$, $P=0.004)$ and total phenolic content of sun-exposed leaves increased with C:N ratios (Fig. 2b, Table 4). Tellimagrandin II content of leaves did not differ by treatment and was not correlated with $\mathrm{C}: \mathrm{N}$ ratios. In stems, light influenced total phenolic content (TPC: light: d.f. $=1, F=15.12, P=0.005$; C:N: d.f. $=1, F=31.53, P=0.0005 ; \mathrm{C}: \mathrm{N} \times$ light: d.f. $=1$, $F=19.34, P=0.002$ ) and total phenolic content of shaded stems decreased with increasing C:N ratios (Fig. 2c, Table 4). Tellimagrandin II content of stems did not differ by treatment and was not correlated with $\mathrm{C}: \mathrm{N}$ ratios.

\section{Discussion}

The chemical profiles of $M$. spicatum and M. sibiricum have many similarities, including their nitrogen, phosphorus, sugar, polysaccharide, and nonpolar compound concentrations and $\mathrm{C}: \mathrm{N}, \mathrm{C}: \mathrm{P}$, and $\mathrm{N}: \mathrm{P}$ ratios. However, some differences in their polyphenol and ash content are apparent that could lead to different interactions with associated aquatic organisms and contribute to the invasive potential of $M$. spicatum. M. spicatum has a higher concentration of carbon that is characterized by an approximately twofold higher content of polyphenols, tellimagrandin II and lignin than $M$. sibiricum. In contrast, $M$. sibiricum has a higher ash content. Ash includes minerals such as calcium carbonate. These differences suggest that $M$. spicatum and $M$. sibiricum exhibit alternate strategies to cope with environmental challenges. The higher concentration of carbon-based defenses in M. spicatum could provide protection from UV light (Rozema et al., 1999) and defend against generalist herbivores and algal and bacterial competitors (Gross et al., 1996; Choi et al., 2002; Cronin et al., 2002; Li et al., 2004), but have little effect on specialist herbivores (Marko et al., 2005), particularly in a new habitat. Relative to $M$. spicatum, the high ash content in $M$. sibiricum may provide a structural defense against both generalist and specialist herbivores by reducing the available caloric value of consumed material or acting as a deterrent both directly or synergistically with other chemicals (Hay et al., 1994; Yufera et al., 1997; Sharfstein and Steinman, 2001).

The irradiance levels in our experiments did not affect the $\mathrm{C}$, $\mathrm{N}$, polyphenolic, and tellimagrandin II content. Both $M$. spicatum and $M$. sibiricum have highest concentrations of phenolic compounds in their apical meristems. Gross (2003) reported an increase in carbon and polyphenolic content in $M$. spicatum under high-light treatments (650 versus $150 \mu \mathrm{mol}$ of photon $\left.\mathrm{m}^{-2} \mathrm{~s}^{-1}\right)$. However, in our conditions, shaded plants 
received $75 \%$ of the irradiance of the high light exposed plants in Gross's study, suggesting that a maximum in polyphenol production is reached at relatively low irradiance. These results support previous reports that polyphenol production is probably constitutive in watermilfoils and generally high compared to other aquatic plants (Smolders et al., 2000; Choi et al., 2002; Li et al., 2004; Cronin and Lodge, 2003).

Polyphenol concentration can also reflect the $\mathrm{C}$ and $\mathrm{N}$ allocation patterns within a plant and a plant's response to the environment (Gross, 2003). In apical meristems, as C:N increased, polyphenols, including T-II content, increased irrespective of light treatment, suggesting that at higher $\mathrm{C}: \mathrm{N}$ ratios, the carbon was allocated to defense. With its canopy formation, milfoil relies on well-defended growing tissues (apical meristems) and apparently invests in more carbon-based allelochemicals (polyphenols) when nitrogen declines.

In leaves, irradiance was a major factor in phenolic content. Sun-exposed and shaded leaves had similar amounts of carbon. Therefore, the carbon in the sun-exposed leaves may be used for the production of lignin which, together with polyphenols, was positively correlated with carbon content. The high C:N ratio and lower $\mathrm{N}$ and polyphenol content in the stems and leaves relative to the apical meristem indicate that carbon in full-sun leaves and stems is allocated to the production of structurally bound polyphenols and indigestible tannins. Conversely, carbon in apical meristems and shaded leaves and stems is allocated to polyphenol production.

Season and substrate type can also affect the chemical composition of milfoils. We observed seasonal variation in nitrogen content and consistent differences in carbon content between populations in lakes versus those grown in controlled tanks. In M. spicatum, nitrogen concentration decreased from July to August, then increased again in September. The dip in N content may be a response to the disjuncture between the rapid growth rate of $M$. spicatum in mid-summer and physiological constraints on $\mathrm{N}$ uptake and availability in sediments (Nichols and Keeney, 1976). In contrast, nitrogen concentration in $M$. sibiricum increased from July to August. These data show that $\mathrm{N}$ uptake patterns vary between species and that these differences lead to divergent patterns of growth and allocation of resources (Spencer et al., 2005).

Seasonal changes in tellimagrandin II content and the proportion of tellimagrandin II to polyphenols were also observed for M. spicatum. Tellimagrandin II content increased from July to September. This could reflect a defensive response to late summer phytoplankton blooms (Goulder, 1969). Gross (2000) reported a peak in tellimagrandin II content in early summer for $M$. spicatum and suggested that this increase could defend against phytoplankton and epiphyte growth in the beginning of the growing season. Further study is needed to determine if seasonally changing levels of tellimagrandin II are related to differences in phytoplankton density and succession patterns. Both M. sibiricum and M. spicatum contained high tellimagrandin II levels in our experiments, which suggests that both species use a similar defense against their common phytoplankton competitors. This is the first reported isolation of tellimagrandin II from $M$. sibiricum.
In conclusion, $M$. spicatum and $M$. sibiricum are very similar chemically but can be distinguished by differences in their carbon and phenolic profiles. The higher concentrations of lignin and polyphenols, including tellimagrandin II, found in $M$. spicatum may facilitate its competitive success in a new environment. These generalized defenses can help to protect it against UV damage, phytoplankton competitors, and generalist herbivores. Conversely, the higher ash content in $M$. sibiricum may help to defend it against specialist herbivores, but make it less able to compete in the presence of the exotic invader.

\section{Acknowledgments}

Assistance with specimen collection and analyses were provided by D. Ward, C. Lemmon, S. Daugherty, S. Coloso, K. Eichstaedt, C. Feldbaum (Konstanz), C. McCollum, K. Mann, and many others. The assistance of Tom Krick with the MS analysis is acknowledged. We thank Dr. George Bowes and two anonymous reviewers for providing comments which improved earlier versions of this manuscript. This work is the result of research sponsored by the Minnesota Sea Grant College Program supported by the NOAA Office of Sea Grant, United States Department of Commerce, under grant No. NOAANA16-RG1046. The U.S. Government is authorized to reproduce and distribute reprints for government purposes, not withstanding any copyright notation that may appear hereon. Additional support was provided by the Minnesota Agricultural Experiment Station and the University of Minnesota Graduate School. This paper is journal reprint No. JR536 of the Minnesota Sea Grant College program.

\section{References}

Aiken, S.G., 1981. A conspectus of Myriophyllum (Haloragaceae) in North America. Brittonia 33, 57-69.

Ceska, O., 1977. Studies on aquatic macrophytes. Part XVII. Final report, University of Victoria, Victoria, British Columbia.

Choi, C., Bareiss, C., Walenciak, O., Gross, E.M., 2002. Impact of polyphenols on growth of the aquatic herbivore Acentria ephemerella. J. Chem. Ecol. 28, 2245-2256.

Cronin, G., Lodge, D.M., 2003. Effects of light and nutrient availability on the growth, allocation, carbon/nitrogen balance, phenolic chemistry, and resistance to herbivory of two freshwater macrophytes. Oecologia 137, 32-41.

Cronin, G., Lodge, D.M., Hay, M.E., Miller, M., Hill, A.M., Horvath, T., Bolser, R.C., Lindquist, N., Wahl, M., 2002. Crayfish feeding preferences for freshwater macrophytes: the influence of plant structure and chemistry. J. Crustacean Biol. 22, 708-718.

Day, R.W., Quinn, G.P., 1989. Comparisons of treatments after an analysis of variance in ecology. Ecol. Monogr. 59, 433-463.

Goulder, R., 1969. Interactions between the rates of production of a freshwater macrophyte and phytoplankton in a pond. Oikos 20, 300-309.

Gross, E.M., 2000. Seasonal and spatial dynamics of allelochemicals in the submersed macrophyte Myriophyllum spicatum L. Verh. Internat. Verein. Limnol. 27, 2116-2119.

Gross, E.M., 2003. Differential response of tellimagrandin II and total bioactive hydrolysable tannins in an aquatic angiosperm to changes in light and nitrogen. Oikos 103, 497-504.

Gross, E.M., Meyer, H., Schilling, G., 1996. Release and ecological impact of algicidal hydrolysable polyphenols in Myriophyllum spicatum. Phytochemistry $41,133-138$. 
Hay, M.E., Kappel, Q.E., Fenical, W., 1994. Synergisms in plant defenses against herbivores: interactions of chemistry, calcification, and plant quality. Ecology 75, 1714-1726.

Hobbie, S.E., 1996. Temperature and plant species control over litter decomposition in Alaskan tundra. Ecol. Monogr. 66, 503-522.

Leu, E., Krieger-Liszkay, A., Goussias, C., Gross, E.M., 2002. Polyphenolic allelochemicals from the aquatic angiosperm Myriophyllum spicatum inhibit photosystem II. Plant Physiol. 130, 2011-2018.

Li, Y.K., Yu, D., Yan, X., 2004. Are polyphenolics valuable in anti-herbivory strategies of submersed freshwater macrophytes? Arch. Hydrobiol. 161, 391-402.

Marko, M.D., Newman, R.M., Gleason, F.K., 2005. Chemically mediated hostplant selection by the milfoil weevil: a freshwater insect-plant interaction. J. Chem. Ecol. 31, 2857-2876.

Moody, M.L., Les, D.H., 2002. Evidence of hybridity in invasive watermilfoil (Myriophyllum) populations. Proc. Natl. Acad. Sci. U.S.A. 99, 1487114876.

Newman, R.M., 2004. Biological control of Eurasian watermilfoil: completion report for 2001-2004 to the Minnesota Dept. of Natural Resources, Ecological Services, URL: http://fwcb.cfans.umn.edu/research/milfoil/pubs/ LCMR2001May04-FinalRepFinal.pdf.

Nichols, D.S., Keeney, D.R., 1976. Nitrogen nutrition of Myriophyllum spicatum: variation of plant tissue nitrogen concentration with season and site in Lake Wingra. Freshwater Biol. 6, 137-144.

Ott, R.L., 1993. An Introduction to Statistical Methods and Data Analysis. Duxbury Press, Belmont, CA, p. 1051.

Rozema, J., van de Staaij, J., OlofBjorn, L., de Bakker, N., 1999. Depletion of stratospheric ozone and solar UV-B radiation: evolution of land plants,
UV-screens and functions of polyphenolics. In: Rozema, J. (Ed.), Stratospheric Ozone Depletion: The effects of Enhanced UV-B Radiation on Terrestrial Ecosystems. Backhuys Publishers, Leiden, The Netherlands, pp. 1-19.

Ryan, M., Melillo, J., Ricca, A., 1990. A comparison of methods for determining proximate carbon fractions of forest litter. Can. J. For. Res. 20, 166-171.

Sharfstein, B., Steinman, A.D., 2001. Growth and survival of the Florida apple snail (Pomacea paludosa) fed 3 naturally occurring macrophyte assemblages. J. N. Am. Benthol. Soc. 20, 84-95.

Smith, C.S., Barko, J.W., 1990. Ecology of Eurasian watermilfoil. J. Aquat. Plant Manage. 28, 55-64.

Smolders, A.J.P., Vergeer, L.H.T., vanderVelde, G., Roelofs, J.G.M., 2000. Phenolic contents of submerged, emergent and floating leaves of aquatic and semi-aquatic macrophyte species: why do they differ? Oikos 91, 307-310.

Spencer, D.F., Ksander, G.G., 1999a. Seasonal changes in chemical composition of Eurasian watermilfoil (Myriophyllum spicatum L.) and water temperature at two sites in northern California: implications for herbivory. J. Aquat. Plant Manage. 37, 61-66.

Spencer, D.F., Ksander, G.G., 1999b. Phenolic acids and nutrient content for aquatic macrophytes from Fall River, California. J. Freshwater Ecol. 14, 197-209.

Spencer, D.F., Ksander, G.G., Whitehand, L.C., 2005. Spatial and temporal variation in RGR and leaf quality of a clonal riparian plant, Arundo donax. Aquat. Bot. 81, 27-36.

Yufera, M., Parra, G., Pascual, E., 1997. Energy content of rotifers (Brachionus plicatilis and Brachionus rotundiformis) in relation to temperature. Hydrobiologia $358,83-87$. 